\title{
Deletion in the S1 Region of Porcine Epidemic Diarrhea Virus Reduces the Virulence and Influences the Virus-Neutralizing Activity of the Antibody Induced
}

\author{
Kuo-Jung Tsai ${ }^{1}$, Ming-Chung Deng ${ }^{1}$, Fun-In Wang ${ }^{2}{ }^{\circledR}$, Shu-Hui Tsai ${ }^{1}$, Chieh Chang ${ }^{1}$, \\ Chia-Yi Chang ${ }^{1, *}$ and Yu-Liang Huang ${ }^{1, *}$ \\ 1 Animal Health Research Institute, Council of Agriculture, Executive Yuan, 376 Chung-Cheng Road, Tansui, \\ New Taipei City 25158, Taiwan; krtsai@mail.nvri.gov.tw (K.-J.T.); mcdeng@mail.nvri.gov.tw (M.-C.D.); \\ shtsai@mail.nvri.gov.tw (S.-H.T.); cchang@mail.nvri.gov.tw (C.C.) \\ 2 School of Veterinary Medicine, National Taiwan University, No. 1, Section 4, Roosevelt Road, Taipei 10617, \\ Taiwan; fiwangvm@ntu.edu.tw \\ * Correspondence: cychang@mail.nvri.gov.tw (C.-Y.C.); ylhuang@mail.nvri.gov.tw (Y.-L.H.); \\ Tel.: +886-2-2621-2111 (ext. 343) (C.-Y.C.); +886-2-2621-2111 (ext. 344) (Y.-L.H.)
}

Academic Editor: Tohru Suzuki

Received: 13 October 2020; Accepted: 30 November 2020; Published: 2 December 2020

\begin{abstract}
Porcine epidemic diarrhea virus (PEDV) causes severe diarrhea and a high rate of mortality in suckling pigs. The epidemic of PEDV that occurred after 2013 was caused by non-insertion and deletion of $\mathrm{S}$ gene (S-INDEL) PEDV strains. During this epidemic, a variant of the non-S-INDEL PEDV strain with a large deletion of 205 amino acids on the spike gene (5-17-V) was also found to co-exist with a non-S-INDEL PEDV without deletion (5-17-O). Herein, we describe the differences in the complete genome, distribution, virulence, and antigenicity between strain 5-17-O and variant strain 5-17-V. The deletion of 205 amino acids was primarily located in the $\mathrm{S}^{\mathrm{O}}$ domain and was associated with milder clinical signs and lower mortality in suckling pigs than those of the 5-17-O strain. The 5-17-V strain-induced antibody did not completely cross-neutralize the 5-17-O strain. In conclusion, the deletion in the S1 region reduces the virulence of PEDV and influences the virus-neutralizing activities of the antibody it induces.
\end{abstract}

Keywords: PEDV; deletion; spike protein; virulence; neutralizing active

\section{Introduction}

Porcine epidemic diarrhea (PED) is a swine disease that causes severe watery diarrhea and vomiting in pigs of all ages. The clinical signs in PED virus (PEDV)-infected pigs are age-dependent, wherein younger pigs have higher morbidity and mortality [1]. In weaned pigs, PEDV affects their innate immunity through a decrease in Peyer's patch M cells and lysozyme expression in Paneth cells [2].

The PED virus is an enveloped, single-stranded, positive-sense RNA virus with the spike (S) protein on the envelope. It belongs to the order Nidovirale, family Coronaviridae, subfamily Coronavirinae, and genus Alphacoronavirus [3,4]. The genome of PEDV is approximately 28 kilobases encoding four non-structural proteins (ORF1a, ORF1b, ORF3a, and ORF3b) and four structural proteins (S, envelope (E), membrane (M), nucleocapsid (N)) [3,4]. The ORF3 protein has been associated with PEDV pathogenicity in that deletions between positions 245 and 295 of ORF3 decrease the virulence of PEDV [5]. The $\mathrm{S}$ protein binds to the aminopeptidase $\mathrm{N}$ receptors and is an important epitope of the neutralizing antibody [6-9]. The M protein plays important roles in viral assembly and the induction 
of interferon-alpha (IFN- $\alpha$ ) [10]. The $N$ protein induces cell-mediated immunity and inhibits IFN- $\beta$ production during virus infection [11].

The PEDV strains are classified as genotypes 1 and 2 based on the $S$ gene's sequences. The strains in genotype 1, designated insertion and deletion of $S$ gene (S-INDEL) of PEDV, were the predominant strains globally prior to 2013. These traditional PEDV strains were reported in England in 1971 [12], Belgium in 1978 [13], Japan in 1982 [14], Spain in 1985 [15], Korea in 1992 [16], China in 2004 [17], and in Thailand [18] and Taiwan [19] in 2007. In 2010, a novel mutated strain of PEDV was found in China, classified as genotype 2, and designated non-S-INDEL PEDV [20,21]. Later, this novel virus was transmitted rapidly throughout countries around the Pacific Ocean including the United States of America (USA), Japan, South Korea, Taiwan, Thailand, Vietnam, Mexico, Peru, the Dominican Republic, Columbia, and Canada in 2013 and 2014 [14,19-24]. It was estimated that over 7 million suckling pigs were lost in the USA during the one-year epidemic [25]. Comparison of the $S$ protein sequences of the S-INDEL PEDV strain revealed that the novel PEDV strain had a 4-amino acid (aa) insertion between positions 55 and 56, a 1-aa insertion between positions 135 and 136, and a 2-aa deletion between positions 158 and 159 [19]. Virulence studies have demonstrated that it is highly pathogenic to suckling pigs $[1,26]$.

In late 2013, the PED outbreak that occurred in Taiwan was also caused by the novel PEDV. Subsequently, two novel PEDV strains (strains 5-17-O and 5-17-V) were isolated from the same diarrhea samples. Comparison of the $S$ genes showed that the 5-17-V strain had a 205-aa deletion in the S1 region. This study was carried out to understand the effects of this deletion on the virus distribution in herds, virulence, and antigenicity between the two novel PEDV strains.

\section{Materials and Methods}

\subsection{Viral Isolation}

The Vero cell line was used to isolate PEDV from swine diarrhea samples using the protocols of Chen (2014) [27]. Briefly, the diarrhea samples were prepared in $10 \%$ emulsion in post-inoculation medium (PI) containing minimum essential medium (MEM) supplemented with $0.02 \%$ yeast extract, $0.3 \%$ tryptose broth, and trypsin $250(10 \mu \mathrm{g} / \mathrm{mL})$. The monolayer Vero cells were inoculated with the emulsion sample at $37{ }^{\circ} \mathrm{C}$ with $5 \% \mathrm{CO}_{2}$ for $2 \mathrm{~h}$. After the inoculation, the PI was added, and the mixture was incubated at $37^{\circ} \mathrm{C}$ with $5 \% \mathrm{CO}_{2}$. When the cytopathic effect (CPE) of cell fusion was present, CPE was confirmed by indirect fluorescent-antibody assay (IFA) using PEDV mAb (DE1-1a clone, from the Animal Health Research Institute, Taiwan).

\subsection{RNA Extraction}

The viral RNA of PEDV was extracted from the culture supernatant and tissue emulsion using the QIAamp ${ }^{\circledR}$ Viral RNA Mini kit following the manufacturer's instructions (Qiagen, Hilden, Germany).

\subsection{Sequencing and Analysis of PEDV's Complete Genome}

The two novel strains (5-17-O and 5-17-V) and one traditional strain (4-2) were sequenced to obtain the complete genome using the methods of Huang (2013) [21] and Chen (2014) [27]. A total of seven fragments of each strain were amplified by reverse-transcription polymerase chain reaction (RT-PCR) using PEDV-specific primer, superscript ${ }^{\circledR}$ III, and high-fidelity Platinum ${ }^{\circledR}$ Taq DNA polymerase. Following the amplification, the product of RT-PCR was gel purified and sequenced by next-generation sequencing with the Illumina MiSeq ${ }^{\mathrm{TM}}$ and TruSeq Nano DNA Library Prep Kit. Finally, the sequences of the full genomes were constructed in CLC Genomics Workbench software and mapped to reference the PEDV strain USA/Indiana/17846/2013 (accession number: KF452323). The full genome of the 5-17-O (MW165327), 5-17-V (MW165328), and 4-2 (MW165329) strains were submitted to the GenBank of the National Center for Biotechnology Information (NCBI). The nucleotide (nt) sequences of the $5^{\prime} \mathrm{UTR}$, ORF1a, ORF1b, S, ORF3, E, M, N, and 3'UTR genes of the reference strains (traditional Taiwanese 
PEDV: 4-2 strain; S-INDEL strain: CV777; non-S-INDEL: USA/Indiana/17846/2013) and two novel PEDV strains (5-17-O and 5-17-V) were compared. Furthermore, the multiplex alignment of the $S$ genes of Taiwanese PEDV strains and PEDV reference strains obtained from GenBank of NCBI was analyzed in DNASTAR software using the Clustal W method. Phylogenetic analysis of the aligned sequences was performed by the neighbor-joining method and by bootstrap analysis with 1000 replicates in the DNASTAR software (DNASTAR Inc., Madison, WI, USA).

\subsection{Distribution of Two Novel PEDV Strains in the Farms of Taiwan}

From the 2013 epidemic, two novel PEDV strains (5-17-O and 5-17-V) were isolated from diarrhea samples. To understand the population distribution of these two novel PEDV strains in farms, a total of 105 diarrhea samples from 64 farms (herds) were collected in the year 2014, and the strains were detected by differential diagnostic RT-PCR. Based on the sequences of the $S$ genes of the two novel PEDV strains, universal primers (SF1 and SR739) for PEDV were designed. The primer sequences of SF1 and SR739 were 5'-TGCTAGTGCGTAATAATGAC-3' and 5' -CCTTCTGGTATGTGGCCATT-3', respectively. The total volume of the reaction, $25 \mu \mathrm{L}$, contained $2.5 \mu \mathrm{L}$ extracted RNA, $1 \times$ DNA polymerase buffer, 4 units of recombinant RNase inhibitor (Promega, Madison, WI, USA), 1 unit of AMV reverse transcriptase (Promega, Madison, WI, USA), 1 unit of GoTaq ${ }^{\circledR}$ Flexi DNA polymerase (Promega, Madison, WI, USA), $0.2 \mu \mathrm{M}$ of deoxyNTP mixture, and $0.4 \mu \mathrm{M}$ of each primer (SF1 and SR739). The reaction conditions involved reverse transcription at $42^{\circ} \mathrm{C}$ for $40 \mathrm{~min}$ and amplification with 1 cycle at $95^{\circ} \mathrm{C}$ for $5 \mathrm{~min}, 35$ cycles of denaturation at $95^{\circ} \mathrm{C}$ for $30 \mathrm{~s}$, annealing at $55^{\circ} \mathrm{C}$ for $30 \mathrm{~s}$, extension at $72{ }^{\circ} \mathrm{C}$ for $60 \mathrm{~s}$, and 1 cycle of final extension at $72{ }^{\circ} \mathrm{C}$ for $10 \mathrm{~min}$. Finally, the products of the RT-PCR were electrophoresed in agarose gel. The predicted RT-PCR amplified products for the 5-17-O and 5-17-V strains were $802 \mathrm{bp}$ and $187 \mathrm{bp}$, respectively.

\subsection{Growth Curves of Two Novel PEDV Strains in the Various Concentration of Trypsin}

To study the effect of trypsin concentration on the replication of novel PEDV strains, the kinetics of PEDV replication were determined. First, PIs with $0.1,1,5$, and $10 \mu \mathrm{g} / \mathrm{mL}$ trypsin were prepared. Monolayer Vero cells in the 6-well plates were inoculated with 0.1 multiplicities of infection (MOI) of 5-17-O or 5-17-V strains at $37^{\circ} \mathrm{C}$ for $2 \mathrm{~h}$. Afterward, the inoculants were removed by washing with PI and replaced with fresh PI. The culture supernatant and cells were harvested at $3 \mathrm{~h}$ intervals between 0 and $27 \mathrm{~h}$ post-inoculation (HPI), and the PEDV titers in 50\% tissue culture infectious doses $\left(\mathrm{TCID}_{50}\right)$ were determined.

\subsection{Characterization of the Virulence In Vivo}

To compare the virulence of the 5-17-O and 5-17-V strains, an animal experiment approved by the Institution Animal Care and Use Committee (IACUC) of the Animal Health Research Institute (AHRI Approval number: A04006) was conducted. Thirty-six PEDV-seronegative, one-week-old, healthy piglets were randomly assigned to 9 groups of 4 and housed separately in 9 rooms. The piglets in groups 1-4 were inoculated orally with $10^{3}, 10^{4}, 10^{5}$, and $10^{6} \mathrm{TCID}_{50}$ of the 5-17-O strain, respectively. Those in groups 5-8 were inoculated orally with $10^{4}, 10^{5}, 10^{6}$, and $10^{7} \mathrm{TCID}_{50}$ of the 5-17-V strain, respectively. Those in group 9 were negative controls inoculated with MEM. After inoculation, the clinical signs, including diarrhea, weight, and body temperature, were recorded during the experimental period. Based on the fecal formation, diarrhea was scored as follows: $0=$ solid; $1=$ soft to pasty; 2 = semi-liquid; 3 = complete liquid. The feces and serum were collected, respectively, daily and at two-day intervals at 0-11 days post-inoculation (DPI). The piglets that died during the experimental period were necropsied. The surviving piglets were necropsied at $14 \mathrm{DPI}$. The viral loads were detected by real-time reverse-transcription PCR (RRT-PCR). The antibody against PEDV was detected by IFA and a virus-neutralizing (VN) assay. 


\subsection{Detection of PEDV Loads by RRT-PCR}

The PEDV loads in the feces were detected by RRT-PCR. The primer and probe in the RRT-PCR of PEDV were designed to target the nucleoprotein gene. The sequences of the primer and probe were 5'-GCTTCTCAGAACAGAGGA-3', 5'-CATCGCGTGATGTTACAC-3', and $5^{\prime}$-FAM-CAATAACAAGTCTCGTAACCAGTCCAA-BHQ1-3'. The total volume of $20 \mu \mathrm{L}$ contained $3 \mu \mathrm{L}$ of extracted nuclear acids, $1 \times$ Kappa Probe Fast qPCR Master mix (KAPA biosystems, Boston, MA, USA), 40 units of SuperScript ${ }^{\mathrm{TM}}$ III Reverse Transcriptase (Invitrogen, Carlsbad, CA, USA), $0.3 \mu \mathrm{M}$ of PEDV probe, and $0.5 \mu \mathrm{M}$ of each PEDV primer. The reaction conditions involved initial incubation at $42^{\circ} \mathrm{C}$ for $30 \mathrm{~min}$ and $94{ }^{\circ} \mathrm{C}$ for $5 \mathrm{~min}$ followed by 45 cycles of denaturation at $95^{\circ} \mathrm{C}$ for $20 \mathrm{~s}$, annealing at $60^{\circ} \mathrm{C}$ for $30 \mathrm{~s}$, and extension at $72{ }^{\circ} \mathrm{C}$ for $30 \mathrm{~s}$. Finally, the threshold line was set at a fluorescence level of 5 .

\subsection{Detection of Anti-PEDV Antibody}

The anti-PEDV antibody in pig serum was detected by IFA. Briefly, Vero cells in 96-well plates were inoculated with $200 \mathrm{TCID}_{50} \mathrm{PEDV}$ at $37^{\circ} \mathrm{C}$ with $5 \% \mathrm{CO}_{2}$ for $16 \mathrm{~h}$. The supernatant was disposed, and the cells were dried at $37^{\circ} \mathrm{C}$ for $1 \mathrm{~h}$ before being fixed with $10 \%$ neutral-buffered formalin at room temperature for $10 \mathrm{~min}$ and then washed $3 \mathrm{x}$ with PBS. The two-fold serially diluted serum sample was added onto wells at $37^{\circ} \mathrm{C}$ for $1 \mathrm{~h}$ and then washed again. Then FITC-labeled goat-anti-swine IgG (Jackson ImmunoResearch Inc., West Grove, PA, USA) was added, and the mixture was held at $37^{\circ} \mathrm{C}$ for $1 \mathrm{~h}$, washed again, and observed under fluorescence microscopy.

\subsection{Virus-Neutralizing Assay for PEDV}

Anti-PEDV-neutralizing antibody in serum was determined in Vero cells using 5-71-V or 5-17-O strains. In a separate 96-well plate, two-fold serially diluted (from 8 to 512 fold) serum samples were mixed with $200 \mathrm{TCID} 50 / 0.1 \mathrm{~mL}$ PEDV (strain $5-17-\mathrm{O}$ or $5-17-\mathrm{V}$ ) at $37^{\circ} \mathrm{C}$ with $5 \% \mathrm{CO}_{2}$ for $2 \mathrm{~h}$. The pre-seeded Vero cells were washed 2 times with phosphate-buffered saline (PBS) before the mixture was transferred and incubated at $37^{\circ} \mathrm{C}$ with $5 \% \mathrm{CO}_{2}$ for $2 \mathrm{~h}$. The mixture was removed from the cells and washed again with PBS before being placed in fresh PI medium and incubated at $37^{\circ} \mathrm{C}$ with $5 \%$ $\mathrm{CO}_{2}$ for 2 days. The cutoff was based on the fusion CPE.

\subsection{Cross-Neutralization in Serum between the 5-17-O and 5-17-V Strains}

Due to the fact that the PEDV's VN antibodies were negative in the sera (see Section 2.6), a total of 66 anti-PEDV sera from the other pig experiments of inactivated 5-17-O and 5-17-V vaccines were collected, comprising 38 samples from 5-17-O vaccinated piglets and 28 samples from 5-17-V vaccinated piglets. The anti-PEDV-neutralizing antibodies in 66 sera were all detected against the 5-17-O and 5-17-V strains.

\subsection{Statistical Analysis}

The Student's $t$-test, carried out in Microsoft Office Excel 2007, was used to compare the differences between the two groups. The comparisons of the groups were analyzed by one-way analysis of variance (ANOVA). The ANOVA combined with Duncan's multiple range test was performed in SAS for Windows 6.12 (SAS Institute Inc., Cary, NC, USA). A $p$-value $<0.05$ was considered significant.

\section{Results}

\subsection{Comparison of Genetic Similarity between 5-17-O and 5-17-V Strains of PEDV}

Differences in protein sequences were found in the ORF1 and $S$ proteins of the two strains, whereas the sequences of other proteins, including $5^{\prime} \mathrm{UTR}, \mathrm{ORF} 3, \mathrm{E}, \mathrm{M}, \mathrm{N}$, and $3^{\prime} \mathrm{UTR}$, were completely 
the same. Strain 5-17-V had one amino acid difference in position 1652 of ORF1a, from A of the 5-17-O strain to $\mathrm{V}$ of $5-17-\mathrm{V}$.

In the $S$ protein, 5-17-V had a deletion of 205 amino acids (Figure 1) and a difference of three amino acids from the 5-17-O strain. The deletion was from the aligned positions 23 to 229 of the amino acids. The three changes from the 5-17-O to the 5-17-V strains were from $S$ to $G$, from $P$ to $L$, and from $\mathrm{P}$ to $\mathrm{Q}$ in the aligned positions 254,506, and 1063, respectively. From the comparison of the deleted locations among the variant non-S-INDEL strains (5-17-V, LC022792, and KM392229), the same gap was located between the aligned positions 34 and 220. Based on the same gap, the gap of each strain extended several amino acids.
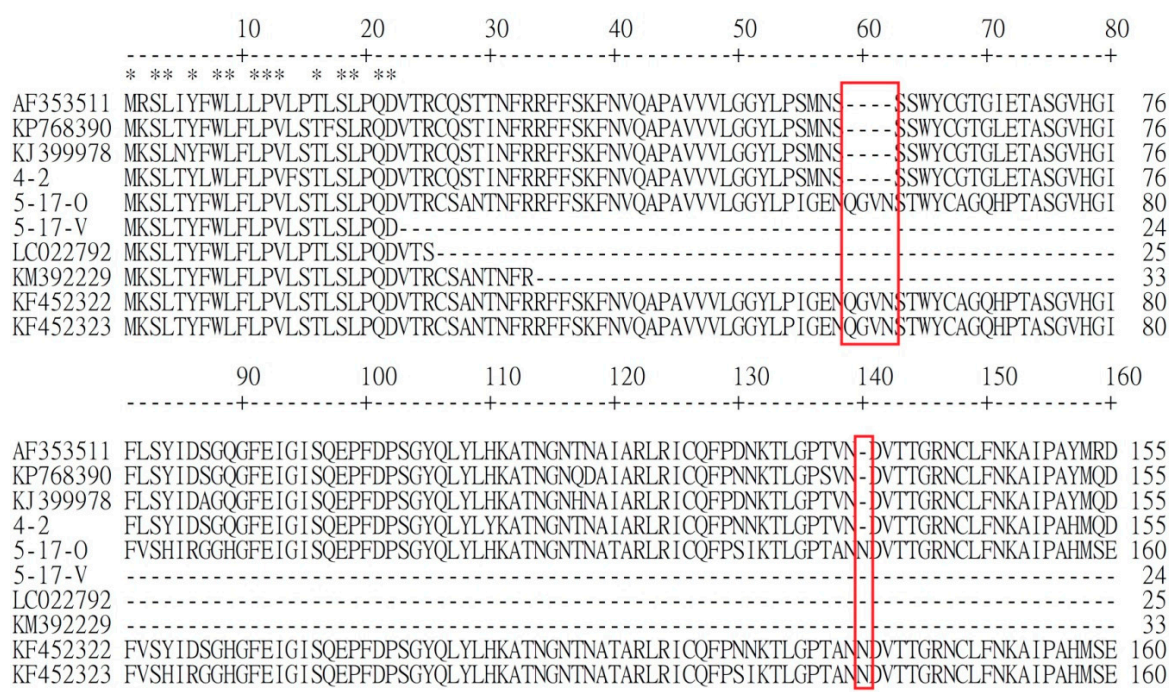
KF452323 FVSHIRGGHGFEIGISQEPFDPSGYOLYLHKATNGNTNATARLRICOFPS IKTLGPTANNDVTTGRNCLFNKAIPAHMSE 160

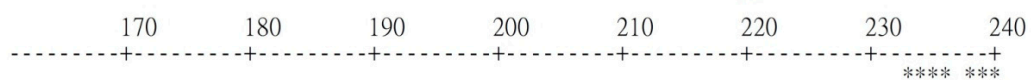

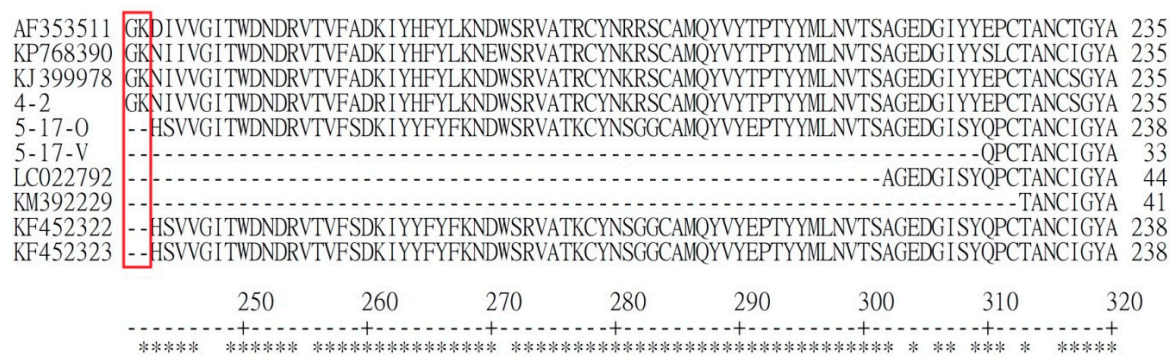

AF353511 ANVFATDSNGHIPEGFSFNNWFLLSNDSTLLHGKVVSNQPLLVNCLLAIPKIYGLGQFFSFNHTMDGVCNGAAVDRAPEA 315 KP768390 VNVFATDSNGHIPEGFSFNNWFLLSNDSTLLHGKVVSNQPLLVNCLLA IPKIYGLGQFFSFNQTMDGACNGVAAQRAPEA 315 KJ 399978 ANVFATDSNGHIPEGFSFNNWFLLSNDSTLLHGKVVSNQPLLVNCLLA IPK IYGLGQFFSFNOTMDGVCNGAAAORAPEA 315 4-2 VNVFATDSNGHIPEGFSFNNWFLLSNDSTLLHGKVVSNQPLLVNCLLAIPKIYGLGQFFSFNQTMDGVCNGAAAORAPEA 315 5-17-0 ANVFATEPNGHIPESESFNNWFLLSNDSTLVHGKVVSNOPLLVNCLLAIPKIYGLGQFFSFNOTIDGVCNGAAVORAPEA 318 5-17-V ANVFATEPNGHIPEG SFNNWFL SNDSTLVHGKVVSNOPLLINCLLAIPKIYGLGOFFSFNOTIDGVCNGAAVQRAPEA 113

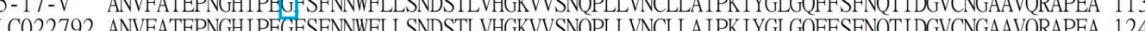
LC022792 ANVFATEPNGHIPEGFSFNNWFLLSNDSTLVHGKVVSNQPLLVNCLLAIPK IYGLGQFFSFNQTIDGVCNGAAVQRAPEA 124 KM392229 ANVFATEPNGHIPEGFSFNNWFLLSNDSTLVHGKVVSNQPLLVNCLLAIPK IYGLGQFFSFNQTIDGVCNGAAVQRAPEA 121

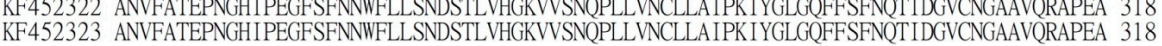

Figure 1. The alignment of the N-terminal 1-320 amino acids in the S protein of the 5-17-O, 5-17-V, 4-2, and porcine epidemic diarrhea virus (PEDV) reference strains. The reference strains consisted of insertion and deletion of S gene (S-INDEL) strains (AF353511, KJ399978, and KP768390), variable non-S-INDEL strains (LC022792 and KM392229), and non-S-INDEL strains (FK452323 and KF452322). The 5-17-O and 5-17-V were newly invaded Taiwanese PEDV strains post-2013, and their inserted and deleted patterns were similar to the non-S-INDEL PEDV genotype strains. The 4-2 strain was the traditional Taiwanese PEDV strain, and its inserted and deleted patterns were the same as the KP768390 (Taiwan/HC070225/2007) and the other S-INDEL PEDV genotype strains (AF353511 and KJ399978). The stars indicate the same amino acid in all strains. The red boxes reveal the inserted and deleted regions between non-S-INDEL and S-INDEL strains. The blue box shows the difference in amino acids between $5-17-\mathrm{O}$ and 5-17-V. 


\subsection{Comparison of Difference of Various Genes between Reference PEDV and Novel Taiwanese PEDV}

Phylogenetic analysis of the S proteins revealed that the 5-17-O and 5-17-V strains were both classified as genotype 2, similar to those of non-S-INDEL strains in the USA, Japan, South Korea, and China (Figure 2). The similarity of the $S$ gene between 5-17-O and the other non-S INDEL strains was from $98 \%$ to $100 \%$. The similarity of the $S$ gene between $5-17-\mathrm{V}$ and the variable non-S INDEL strains (LC022792 and KM 392229) was from 99.3\% to 99.7\%. On the other hand, the traditional Taiwanese PEDV strain, 4-2, was classified as group 1 (S-INDEL) and had a similarity of $97.8 \%$ to the S gene from KP768390 (Taiwan/HC070225/2007).

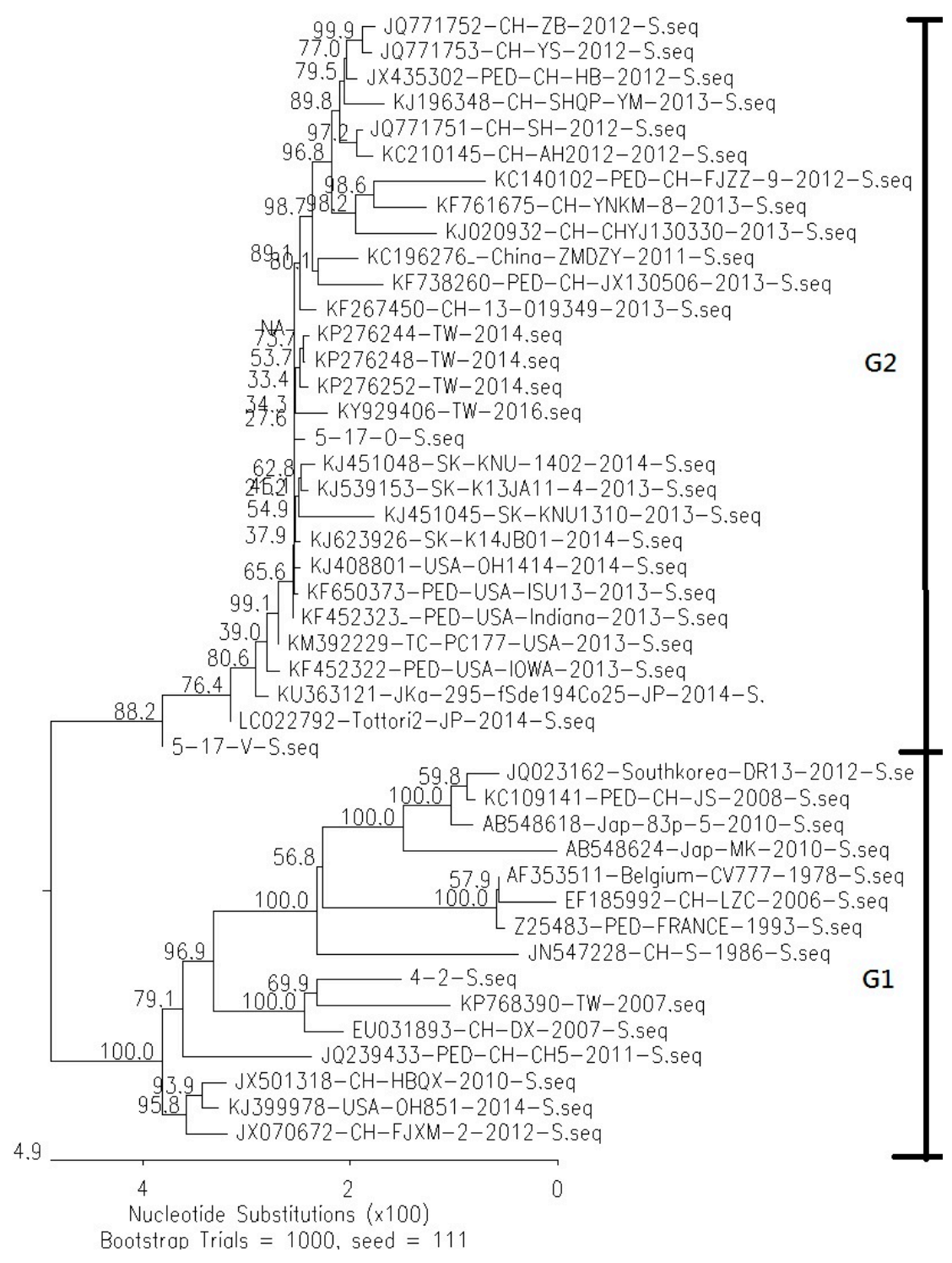

Figure 2. The results of phylogenetic analysis in the spike genes between Taiwanese PEDV and reference PEDV strains are shown. The sequence of the $S$ gene in the PEDVs was aligned and performed in the DNASTAR software (version 7.1.0) using the neighbor-joining methodology with 1000 replicates in bootstrapping analysis. The 5-17-O, 5-17-V, and non-S-INDEL PEDV strains were classified as group 2 (G2). However, the traditional Taiwanese PEDV strains (4-2 and KP768390) and the S-INDEL PEDV strains were classified as group 1 (G1).

The similarity of nucleotides and amino acids in various genes between the reference strains and the two novel Taiwanese PEDV strains (5-17-V and 5-17-O) were compared, and the results of the 5-17-V 
and 5-17-O strains were the same for the 5'UTR, ORF1a, ORF1b, ORF3, E, M, N, and 3'UTR genes; the similarity of nucleotides was between $99.6 \%$ and $100 \%$ for the non-S-INDEL strain (KF452323) and between $96.7 \%$ and $99.4 \%$ for the S-INDEL strain (MW165329 and AF353511) (Table 1). However, a deletion of 28 amino acids in the ORF1a gene was found in the 4-2 strain, located between the aligned positions 1011 and 1038. The similarity of the S proteins between the 5-17-O and S-INDEL strains was from $93.6 \%$ to $95.2 \%$. The difference between 5-17-O and 4-2 strains was the same as the pattern between S-INDEL and non-S-INDEL strains in that 5-17-O had a 4-aa insertion between aligned positions 59 and 562, a 1-aa insertion in aligned position 140, and a 2-aa deletion between aligned positions 161 and 162 (Figure 1).

Table 1. The similarity of nucleotides and amino acids in the various genes between reference PEDV strains and novel Taiwanese PEDV strains.

\begin{tabular}{|c|c|c|c|c|c|c|c|}
\hline \multirow{2}{*}{ Strains } & \multirow{2}{*}{ Gene } & \multicolumn{2}{|c|}{$\begin{array}{c}4-2^{c} \\
(M W 165329)\end{array}$} & \multicolumn{2}{|c|}{$\begin{array}{c}\text { CV777 } \\
\text { (AF353511) }\end{array}$} & \multicolumn{2}{|c|}{$\begin{array}{c}\text { USA/Indiana/17846/2013 } \\
\text { (KF452323) }\end{array}$} \\
\hline & & Nucleotide & Amino Acids & Nucleotide & Amino Acids & Nucleotide & Amino Acids \\
\hline \multirow{10}{*}{$\begin{array}{l}5-17-\mathrm{O} \\
(5-17-\mathrm{V})\end{array}$} & $5^{\prime}$-UTR & $98.9^{a}$ & - & 98.9 & - & 100 & - \\
\hline & ORF1a & $98.6^{b}$ & 98.7 & 97.7 & 97.7 & 99.9 & 99.9 \\
\hline & ORF1b & 98.7 & 98.4 & 97.8 & 99.3 & 100 & 100 \\
\hline & ORF3 & 96.7 & 96.4 & 96.7 & 96.0 & 99.6 & 99.1 \\
\hline & $c$ & 94.9 & 95.2 & 94.0 & 93.6 & 99.9 & 99.8 \\
\hline & $S$ & (96.9) & (97.6) & (94.7) & (95.6) & (99.0) & (99.7) \\
\hline & $\mathrm{E}$ & 97.4 & 98.7 & 97.0 & 98.7 & 100 & 100 \\
\hline & M & 98.1 & 99.6 & 98.2 & 98.7 & 100 & 100 \\
\hline & $\mathrm{N}$ & 98.6 & 99.3 & 96.0 & 97.1 & 100 & 100 \\
\hline & $3^{\prime}$-UTR & 99.4 & - & 97.9 & - & 100 & - \\
\hline
\end{tabular}

a The unit of similarity for nucleotides and amino acids is percentage (\%). ${ }^{\mathrm{b}}$ The deletion of 28 amino acids in the ORF1a region of the 4-2 strain was located between the aligned positions 1011 and 1038. ' Strains 4-2 and CV777 belonged to the S-INDEL strain. Strain USA/Indiana/17846/2013 belonged to the non-S-INDEL PEDV strain.

\subsection{Population Distribution of the 5-17-O and 5-17-V Strains in Taiwan}

A total of 105 diarrhea samples from 64 farms were examined by differential diagnostic RT-PCR of PEDV. The results showed that 73 samples from 46 farms had $802 \mathrm{bp}$ of RT-PCR product and belonged to the 5-17-O strain. In the 5-17-O positive samples, 10 samples from six farms also had $187 \mathrm{bp}$ of RT-PCR product and belonged to the 5-17-V strain. The other 32 samples were negative according to the differential diagnostic RT-PCR of PEDV.

\subsection{Comparison of Replication Kinetics between the 5-17-O and 5-17-V Strains in an In Vitro Experiment}

The replication kinetics of the two novel PEDV strains in various concentrations of trypsin were determined by an in vitro study. The growth curves of the two PEDV strains in each condition were established and compared to each other at the same time (Figure 3). The growth curves of the two PEDV strains in the same condition did not differ significantly. The PEDV titer in each condition did not significantly increase in the early 9 HPI. From 9 to 18 HPI, the titers of the 5-17-O and 5-17-V strains in the high trypsin concentrations $(5$ and $10 \mu \mathrm{g} / \mathrm{mL})$ increased exponentially from $10^{4.9}$ to $10^{6.85} \mathrm{TCID}_{50} / \mathrm{mL}$ of $5-17-\mathrm{O} / 5,10^{4.84}$ to $10^{6.65} \mathrm{TCID}_{50} / \mathrm{mL}$ of $5-17-\mathrm{O} / 10,10^{5.15}$ to $10^{6.62} \mathrm{TCID}_{50} / \mathrm{mL}$ of $5-17-\mathrm{V} / 5$, and $10^{5.02}$ to $10^{6.79} \mathrm{TCID}_{50} / \mathrm{mL}$ of $5-17-\mathrm{V} / 10$. The titers of the $5-17-\mathrm{V}$ and $5-17-\mathrm{O}$ strains in the high trypsin concentrations were significantly higher than that of the low trypsin concentrations $(0.1$ and $1 \mu \mathrm{g} / \mathrm{mL})$ at 12, 15, and $18 \mathrm{HPI}$. After $18 \mathrm{HPI}$, the titers of the two PEDV strains in the high trypsin concentrations gradually decreased. In the low trypsin concentration, the titer of the 5-17-O strain slowly increased from $10^{4.5}$ to $10^{5.81} \mathrm{TCID}_{50} / \mathrm{mL}$ of $5-17-\mathrm{O} / 0.1$ and from $10^{4.54}$ to $10^{5.81} \mathrm{TCID} 50 / \mathrm{mL}^{2}$ of 5-17-O/1 at 9 to $27 \mathrm{HPI}$, and the peak titer was at $27 \mathrm{HPI}$. However, the lower titer was revealed in the $5-17-\mathrm{V} / 0.1$ and $5-17-\mathrm{V} / 1$. The peak titers of the $5-17-\mathrm{V}$ strain in 0.1 and $1 \mu \mathrm{g} / \mathrm{mL}$ trypsin were only $10^{4.9} \mathrm{TCID}_{50} / \mathrm{mL}$ at $15 \mathrm{HPI}$ and $10^{5.5} \mathrm{TCID}_{50} / \mathrm{mL}$ at $18 \mathrm{HPI}$, respectively. 


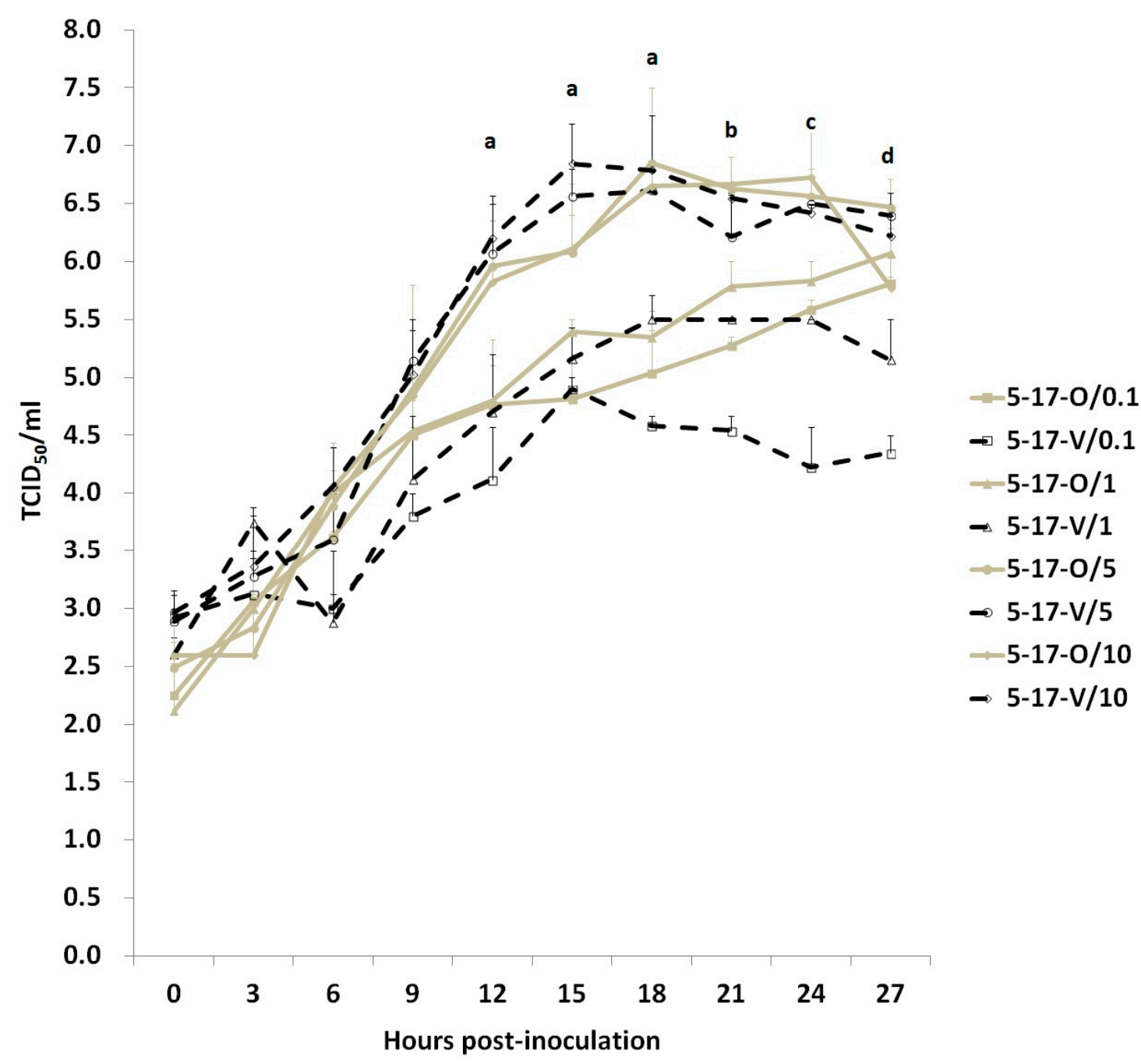

Figure 3. The growth curves of the 5-17-O and 5-17-V strains among various trypsin concentrations $(0.1-10 \mu \mathrm{g} / \mathrm{mL})$ of post-inoculation medium (PI) were determined in Vero cells. The solid and gray lines represent the 5-17-O strain. The dotted and black lines represent the 5-17-V strain. The square, triangle, ring, and diamond symbols represent $0.1,1,5$, and $10 \mu \mathrm{g} / \mathrm{mL}$ of trypsin, respectively. ${ }^{\text {a }}$ Indicates that the titers of $5-17-\mathrm{V}$ and $5-17-\mathrm{O}$ in the high trypsin concentrations ( 5 and $10 \mu \mathrm{g} / \mathrm{mL}$ ) were significantly higher than that of the low trypsin concentrations $(0.1$ and $1 \mu \mathrm{g} / \mathrm{mL}) .{ }^{b}$ Indicates that $5-17-\mathrm{V} / 10,5-17-\mathrm{O} / 5$, and 5-17-O/10 had significantly higher titers than $5-17-\mathrm{V}$ and $5-17-\mathrm{O}$ in the low trypsin concentrations. ${ }^{c}$ Indicates that 5-17-O in the high trypsin concentrations had a significantly higher titer than $5-17-\mathrm{V}$ and 5-17-O in the low trypsin concentrations. ${ }^{\mathrm{d}}$ Indicates that 5-17-O/5, 5-17-V/5, and 5-17-V/10 had significantly higher titers than 5-17-V/0.1 and 5-17-V/1.

\subsection{Comparison of Virulence between the 5-17-O and 5-17-V Strains In Vivo}

\subsubsection{Clinical Signs}

The piglets in the control group were all healthy during the experimental period. The piglets inoculated with PEDV all exhibited diarrhea within 2 DPI, which continued for 3-9 DPI. The averaged diarrhea day (period) was affected by the inoculated dosages, wherein those inoculated with $10^{6}$ and $10^{7} \mathrm{TCID}_{50}$ of 5-17-V (groups 7 and 8 ) showed significantly more diarrhea days than those with $10^{4}$ and $10^{5} \mathrm{TCID}_{50}$ of 5-17-V (groups 5 and 6) (Table 2). No significant difference in diarrhea days was found in the 5-17-O strain group (groups 1-4). To compare the extent of the diarrhea, more severe diarrhea scores were found at 3-5 DPI in the piglets with $10^{5}$ or $10^{6} \mathrm{TCID}_{50}$ of 5-17-O (groups 3 and 4) or $10^{7} \mathrm{TCID}_{50}$ of $5-17-\mathrm{V}$ (group 8) than in the other groups (Figure 4). Comparing the diarrhea scores 
in low-dose inoculated piglets between $5-17-\mathrm{O}$ and 5-17-V, piglets with $10^{3}$ or $10^{4} \mathrm{TCID}_{50}$ of 5-17-O (groups 1 and 2) also had more severe diarrhea than piglets with $10^{4}$ or $10^{5} \mathrm{TCID}_{50}$ of $5-17-\mathrm{V}$ (groups 5 and 6) at 3-4 DPI. During the experimental period, 50\% mortality occurred in piglets inoculated with $10^{6} \mathrm{TCID}_{50}$ of $5-17-\mathrm{O}$ (group 4 ) and $10^{7} \mathrm{TCID}_{50}$ of 5-17-V (group 8) (Table 2). Two piglets in group 4 $\left(5-17-\mathrm{O} / 10^{6}\right)$ died separately at 5 and 6 DPI. Two piglets in group $8\left(5-17-\mathrm{V} / 10^{7}\right)$ died separately at 6 and 8 DPI. Before the piglets' death, they showed continual severe diarrhea for more than three days.

Table 2. The clinical signs of piglets inoculated with various PEDV dosages.

\begin{tabular}{cccccc}
\hline Group & $\begin{array}{c}\text { Strain/Inoculated } \\
\text { Load (TCID } 50\end{array}$ & Diarrhea\%/Shedding\% & $\begin{array}{c}\text { Average } \\
\text { Diarrhea Days }\end{array}$ & $\begin{array}{c}\text { Average } \\
\text { Shedding Days }\end{array}$ & Mortality (\%) \\
\hline 1 & $5-17-\mathrm{O} / 10^{3}$ & $100 / 100$ & $4.5 \pm 0.9^{\mathrm{c}, \mathrm{d}}$ & $7.8^{2} \pm 1.5^{\mathrm{b}}$ & 0 \\
2 & $5-17-\mathrm{O} / 10^{4}$ & $100 / 100$ & $5.0 \pm 1.9^{\mathrm{c}, \mathrm{d}}$ & $8.3 \pm 1.1^{\mathrm{b}}$ & 0 \\
3 & $5-17-\mathrm{O} / 10^{5}$ & $100 / 100$ & $6.0 \pm 0.7^{\mathrm{c}, \mathrm{d}}$ & $8.3 \pm 1.1^{\mathrm{b}}$ & 0 \\
4 & $5-17-\mathrm{O} / 10^{6}$ & $100 / 100$ & $6.0 \pm 1.4^{\mathrm{c}, \mathrm{d}}$ & $8.5 \pm 2.9^{\mathrm{b}}$ & $50(2 / 4)^{*}$ \\
5 & $5-17-\mathrm{V} / 10^{4}$ & $100 / 100$ & $1.5 \pm 0.9^{\mathrm{a}, \mathrm{b}}$ & $6.3 \pm 0.8^{\mathrm{b}}$ & 0 \\
6 & $5-17-\mathrm{V} / 10^{5}$ & $100 / 100$ & $3.5 \pm 2.6^{\mathrm{b}, \mathrm{c}}$ & $7.5 \pm 0.5^{\mathrm{b}}$ & 0 \\
7 & $5-17-\mathrm{V} / 10^{6}$ & $100 / 100$ & $9.0^{\mathrm{e}} \pm 2.4^{\mathrm{e}}$ & $7.3 \pm 0.4^{\mathrm{b}}$ & 0 \\
8 & $5-17-\mathrm{V} / 10^{7}$ & $100 / 100$ & $7.3 \pm 2.0^{\mathrm{d}, \mathrm{e}}$ & $6.3 \pm 1.4^{\mathrm{b}}$ & $50(2 / 4)^{* *}$ \\
9 & MEM & 0 & $0.0^{\mathrm{a}} \pm 0.0^{\mathrm{a}}$ & $0.0^{\mathrm{a}} \pm 0.0^{\mathrm{a}}$ & 0 \\
\hline
\end{tabular}

* Two piglets in group 4 died separately at 5 and 6 days post-inoculation (DPI). ${ }^{*}$ Two piglets in group 8 died separately at 6 and 8 DPI. ${ }^{\text {a-e }}$ Values with different superscripts indicate that the differences among groups are statistically significant $(p<0.05)$. TCID 50 : 50\% tissue culture infectious doses.

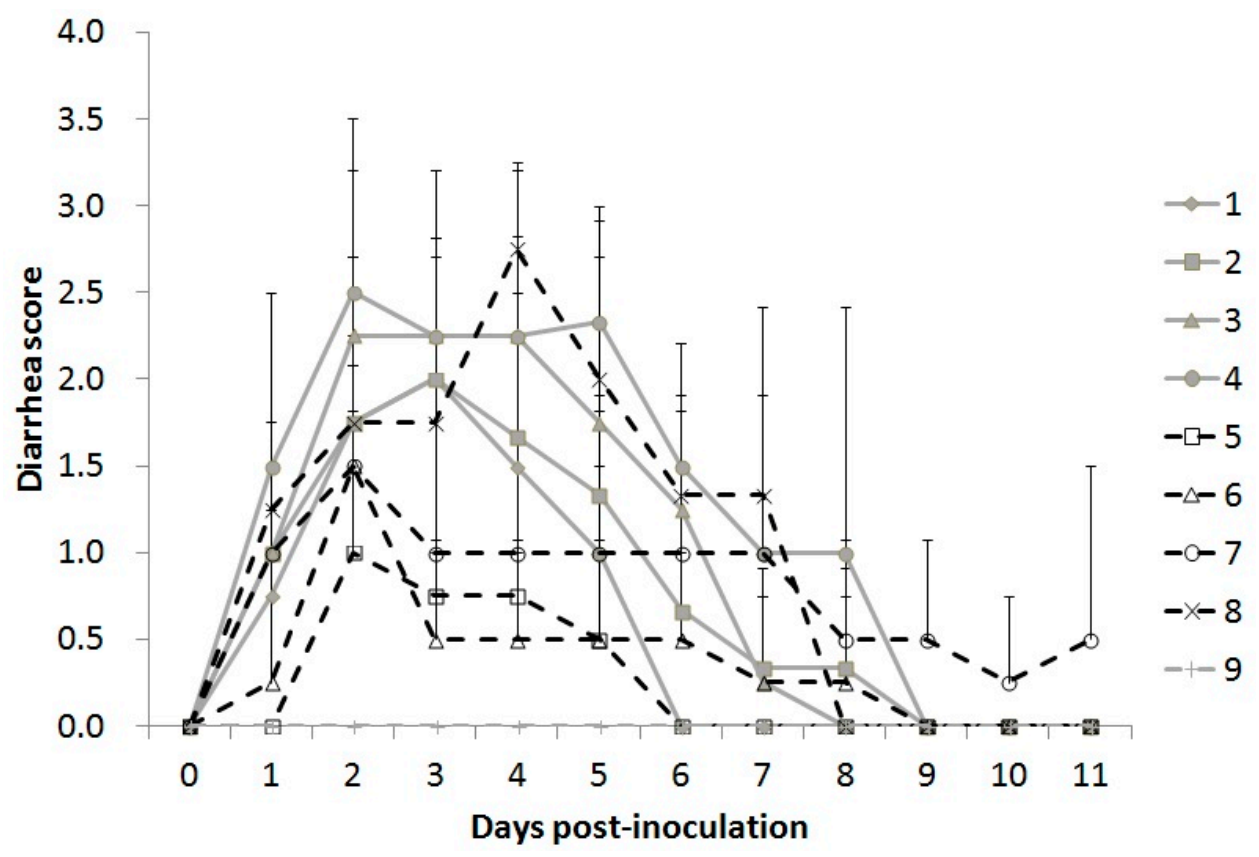

Figure 4. The averaged diarrhea scores of each group during the experimental period. The piglets in groups 1 to 4 were inoculated with $10^{3}$ to $10^{6} \mathrm{TCID}_{50}$ of 5-17-O (solid and gray lines), respectively. The piglets in groups 5 to 8 were inoculated with $10^{4}$ to $10^{7} \mathrm{TCID}_{50}$ of $5-17-\mathrm{V}$ (dotted and black lines), respectively. Group 9 was the negative control. The diarrhea was scored as follows: $0=$ solid; $1=$ soft to pasty; 2 = semi-liquid; 3 = complete liquid.

\subsubsection{Viral Shedding in Feces}

No PEDV was detected in the feces of piglets in the negative controls (group 9) during the experimental period. The PEDV shedding from feces was found in all piglets inoculated with PEDV (Table 2). In piglets inoculated with the 5-17-O strain (groups 1-4), PEDV shedding was detected within 2 DPI and continued to 6 DPI. After 7 DPI, some piglets recovered gradually, but in each group, one or more piglets continuously shed PEDV in feces until the end of the experiment. The earliest PEDV 
shedding time was detected at 1 DPI in piglets inoculated with $10^{7} \mathrm{TCID}_{50}$ of the $5-17-\mathrm{V}$ strain (group 8 ) and $10^{6} \mathrm{TCID}_{50}$ of the 5-17-O strain (group 4). Comparison of average shedding days between the 5-17-O and 5-17-V strains showed no significant difference (Table 2).

3.5.3. The Titer of Anti-PEDV Serum Antibody Detected by IFA and Neutralizing Assay in Experimentally Infected Pigs

The anti-PEDV antibody was not detected in any piglets by IFA before the in vivo experiment. At 6 DPI, anti-PEDV antibodies were detected by IFA in the piglets in the 5-17-V inoculation (groups $5-8$ ), and the titer gradually increased from 6 to 10 DPI. However, in 5-17-O inoculated piglets (groups $1-4$ ), only two piglets with inoculation of $10^{6} \mathrm{TCID}_{50}$ (group 8) had anti-PEDV antibodies at 10 DPI. However, no neutralizing antibodies against the 5-17-V and 5-17-O strains were detected in the sera of all piglets at $10 \mathrm{DPI}$.

\subsection{Cross-Neutralization between the 5-17-O and 5-17-V Strains}

As the VN antibodies of the pig sera were negative, additional sera from the other piglets immunized with inactivated $5-17-\mathrm{O}$ or $5-17-\mathrm{V}$ vaccines were collected to assay for the cross-neutralization between 5-17-O and 5-17-V. Based on the serum origin and anti-homologous PEDV neutralizing antibodies, a total of 66 sera were divided into 23 samples of 5-17-O low (4 to 32 fold), 15 samples of 5-17-O high (64 to 512 fold), 17 samples of 5-17-V low (8 to 32 fold), and 11 samples of $5-17-\mathrm{V}$ high (64 to 512 fold). The VN titers against the strain 5-17-V in sera of the 5-17-O low, 5-17-V low, and 5-17-V high groups were all equal/similar or higher than that against strain 5-17-O. The ratio of the VN titers against the 5-17-V strain were over four-fold higher than that of the VN titer against the 5-17-O strain: $30.4 \%(7 / 23), 47.1 \%(8 / 17)$, and $72.7 \%(8 / 11)$ in the $5-17-\mathrm{O}$ low; $5-17-\mathrm{V}$ low and $5-17-\mathrm{V}$ high, respectively. The neutralizing titers against $5-17-\mathrm{V}$ strains in the $5-17-\mathrm{O}$ low $(5.0 \pm 2.3 \log 2)$, $5-17-\mathrm{V}$ low $(2.9 \pm 1.6 \log 2)$, and 5-17-V high $(6.7 \pm 1.0 \log 2)$ samples were, significantly higher than those against $5-17-\mathrm{O}(3.6 .0 \pm 1.1 \log 2$ of $5-17-\mathrm{O}$ low; $2.9 \pm 1.6 \log 2$ of $5-17-\mathrm{V}$ low; $4.1 \pm 1.6 \log 2$ of $5-17-\mathrm{V}$ high, respectively) (Figure 5). However, those in the 5-17-O high sample were not significantly different in the $\mathrm{VN}$ assay against the $5-17-\mathrm{V}$ and $5-17-\mathrm{O}$ strains.

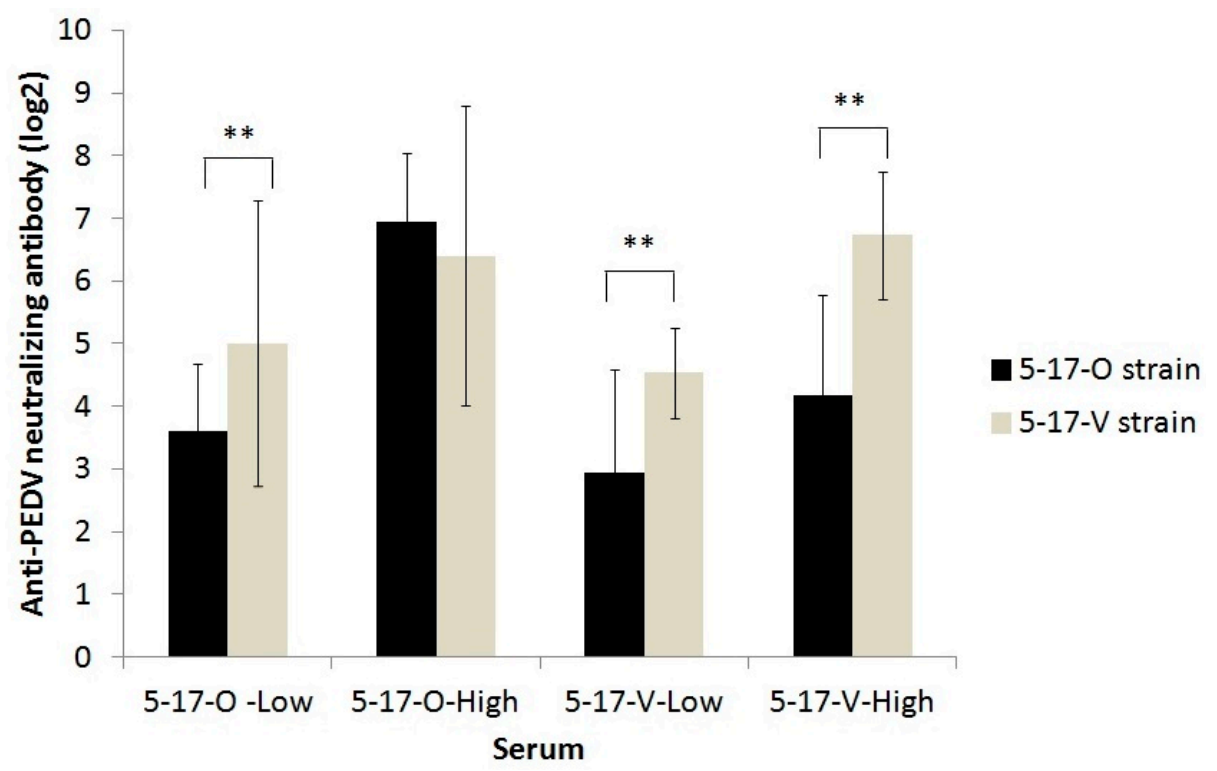

Figure 5. Cross-neutralizing antibody against the 5-17-O and 5-17-V strains between the sera of 5-17-O and $5-17-V$ vaccinated piglets. Based on the serum origin and anti-homologous PEDV neutralizing antibodies, a total of 66 sera were divided into 23 samples of 5-17-O low (4 to 32 fold), 15 samples of 5-17-O high (64 to 512 fold), 17 samples of 5-17-V low (8 to 32 fold), and 11 samples of 5-17-V high (64 to 512 fold). ${ }^{* *}$ Indicates a significant difference $(p<0.01)$. 


\section{Discussion}

The $S$ protein is the target gene for evaluating the evolution of PEDV and the origin of PEDV transmission. The non-S-INDEL PEDV, with insertion and deletion in the $\mathrm{S}$ protein, has rapidly spread globally and possibly originated from the AH2012 strain [21,27]. In the 2013 PED epidemic, when non-S-INDEL PEDV first emerged in Taiwan [19], we found a variant of the non-S-INDEL PEDV strain $(5-17-\mathrm{V})$ with a deletion of 205 amino acids in the S1 region during the routine diagnosis of swine diseases. The PEDV with large deletions in the S1 region was also found in Japan (deletion of 194 amino acids) [28] and the USA (deletions of 194 to 204 amino acids) [29]. Nevertheless, the size and locations of the deletions in the S1 region differed slightly among these various PEDV strains. The deletion size ranged from 194 to 205 amino acids, and the segment between residues 34 and 212 of the $\mathrm{S}$ protein was completely absent. The deletion of 205 amino acids also occurred in the 5-17-V strain and JKa-295/CS1de205 (KU363101) [30] but in different locations. The variant non-INDEL PEDV strain, $5-17-\mathrm{V}$, was first found in Taiwan.

The phylogenetic analysis of the $\mathrm{S}$ gene revealed that 5-17-O was a Taiwanese non-S-INDEL PEDV strain. The inserted and deleted patterns and sequences in the non-S-INDEL found in Taiwan were highly similar to those of the non-S-INDEL strains found in the USA, Japan, South Korea, and China and was different from that of the traditional Taiwanese PEDV strain. These results indicated that the Taiwanese non-S-INDEL was, in fact, a new invasive strain. The same discourse was demonstrated in a recent study showing that the Taiwanese non-S-INDEL PEDV strains were highly related with the non-S-INDEL strain in the USA [19]. In addition, the variable non-S-INDEL strain, similar to the $5-17-\mathrm{V}$ strain with a large deletion, was reported in the USA and Japan. Our investigation found that the 5-17-V and 5-17-O usually co-existed in the same sample. Therefore, the piglets might be simultaneously infected with both the $5-17-\mathrm{V}$ and $5-17-\mathrm{O}$ strains, suggesting that the $5-17-\mathrm{V}$ invasion followed that of the 5-17-O invasion at the same stage.

Viral evolution allows viruses to adapt to changes in host environments, leading to the development of various strains. The pathways of viral evolution include mutation, insertion, deletion, and recombination of genes. The non-S-INDEL PEDV strain is a new PEDV strain of genotype 2 with mutation, insertion, and deletion as compared with the traditional PEDV strain of genotype 1. In this study, we found that the variant $5-17-\mathrm{V}$ strain coexisted in $14 \%$ of cases $(10 / 73$ samples, see Section 3.3) of non-S-INDEL PEDV infection. This large deletion of the $S$ protein has also occurred in the evolutions of other coronaviruses such as transmissible gastroenteritis virus (TGEV) [31] and Middle East respiratory syndrome coronavirus [32]. The gene deletion of TGEV led to a change in the virus tropism from intestinal enterocytes to respiratory tissues, indicating that the deletion of the $S$ protein is one pathway in the process of coronavirus evolution.

Trypsin plays an important role during PEDV replication. Recent studies and this study demonstrate that insufficient load and lack of trypsin decrease the efficacy of PEDV production in cells [33,34]. Furthermore, we also found that the replication of the 5-17-V strain was significantly more trypsin dependent than the 5-17-O strain. The difference in trypsin dependence between these two strains is presumed to be associated with the deletion of the PEDV S protein. Strain 5-17-V had the deletion of 205 amino acids of the $\mathrm{S}$ protein located mainly in the $\mathrm{S} 1^{\mathrm{O}}$ domain and partially in the $\mathrm{S} 1^{\mathrm{A}}$ domain. During PEDV infection, trypsin can cleave the S protein into S1 and S2 subunits, leading the S1 subunit to bind to the aminopeptidase $\mathrm{N}$ receptor [33,34]. If the $\mathrm{S} 1$ subunit is thus incomplete, it could possibly lower the binding capability of PEDV. In addition, trypsin is able to enhance the viral budding and fusion formation of CPE in infected cells [33,34]. The effect of both a lower trypsin concentration and an incomplete $S$ protein of PEDV could significantly decrease the efficacy of PEDV replication.

The $S$ protein is one of the determinants of virulence in the pathogenesis of PEDV [35], wherein high virulence in the suckling pigs occurred with the non-S-INDEL PEDV strains. When the S1 region of S-INDEL PEDV strains was experimentally replaced with that of non-S-INDEL strains, more severe clinical signs were observed in suckling pigs infected with the recombined strain [33]. In this study, we demonstrated milder clinical signs and lower mortality in suckling pigs with 5-17-V 
infection, indicating that the deletion of 205 amino acids decreased the virulence of PEDV. The variant non-S-INDEL (5-17-V), a low-virulent PEDV strain, has the advantage of easier attenuation, but its antigenicity to induce the antibody production is not completely characterized. For the development of a vaccine candidate, the reduced antigenicity of the variant $5-17-\mathrm{V}$ strain would be improved by an adjuvant to further induce the adaptive immunity. In addition, higher infection doses induced more severe diarrhea and higher mortality in suckling pigs, as found in other studies [36,37], implying that the infectious dose directly influences the PEDV pathogenesis.

The receptor-binding domain of PEDV, which resides in the S protein, is also associated with the induction of a neutralizing antibody $[7,8]$. The $S 1^{\mathrm{B}}$ domain of PEDV attaches to the porcine aminopeptidase $\mathrm{N}$ (pAPN) receptor during virus entry [9,38]. The $\mathrm{S}^{\mathrm{O}}$ domain, which binds to Sia, is associated with the hemagglutinating activities of PEDV $[39,40]$. The large deletion of $S$ in the 5-17-V strain, located mainly in the $\mathrm{S} 1^{\mathrm{O}}$ domain and partially in the $\mathrm{S}^{\mathrm{A}}$ domain, induced a neutralizing antibody that has a lower capacity to cross-neutralize 5-17-O (Figure 5), giving the virus a survival advantage. The neutralizing epitopes of the $\mathrm{S}^{\mathrm{O}}$ domain were also determined [41], suggesting that positions $23-227$ of the $S$ protein contain the potent neutralizing epitopes, and this deletion affected the neutralizing activity of PEDV-induced serum.

\section{Conclusions}

In conclusion, the variant PEDV (5-17-V) with a large deletion in S was first found in Taiwan and commonly coexists in herds infected with PEDV without a large deletion in S. This large deletion, primarily located in the $\mathrm{S}^{\mathrm{O}}$ domain, is associated with the reduced virulence of PEDV in vivo and influences the neutralizing activities of the antibody induced by the variant PEDV to cross-neutralize those PEDVs without a large deletion on S, providing the virus a survival advantage.

Author Contributions: Conceptualization, K.-J.T., Y.-L.H.; methodology, K.-J.T., M.-C.D., S.-H.T., C.C.; validation, C.-Y.C., Y.-L.H.; resources, M.-C.D., data curation, C.-Y.C., Y.-L.H.; writing-original draft preparation, K.-J.T., Y.-L.H.; writing-review and editing, C.-Y.C., F.-I.W., Y.-L.H.; supervision, F.-I.W.; funding acquisition, M.-C.D. All authors have read and agreed to the published version of the manuscript.

Funding: This research was supported in part by grant 104AS-10.1.1-HI-H3 from the Council of Agriculture.

Acknowledgments: We especially thank our colleagues in the division of Hog Cholera Research for their assistance in the animal experiments.

Conflicts of Interest: The authors declare no conflict of interest.

\section{References}

1. Jung, K.; Annamalai, T.; Lu, Z.; Saif, L.J. Comparative pathogenesis of US porcine epidemic diarrhea virus (PEDV) strain PC21A in conventional 9-day-oldnursing piglets vs. 26-day-old weaned pigs. Vet. Microbiol. 2015, 178, 31-40. [CrossRef]

2. Chen, Y.M.; Helm, E.T.; Gabler, N.; Hostetter, J.M.; Burrough, E.R. Alterations in Intestinal Innate Mucosal Immunity of Weaned Pigs During Porcine Epidemic Diarrhea Virus Infection. Vet. Pathol. 2020, 57, 642-652. [CrossRef]

3. Vlasova, A.N.; Halpin, R.; Wang, S.; Ghedin, E.; Spiro, D.J.; Saif, L.J. Molecular characterization of a new species in the genus Alphacoronavirus associated with mink epizootic catarrhal gastroenteritis. J. Gen. Virol. 2011, 92, 1369-1379. [CrossRef]

4. Woo, P.C.; Lau, S.K.; Lam, C.S.; Lau, C.C.; Tsang, A.K.; Lau, J.H.; Bai, R.; Teng, J.L.; Tsang, C.C.; Wang, M.; et al. Discovery of seven novel mammalian and avian coronaviruses in the genus deltacoronavirus supports batcoronaviruses as the gene source of alphacoronavirus and betacoronavirus and avian coronaviruses as the gene source of gammacoronavirus and deltacoronavirus. J. Virol. 2012, 86, 3995-4008.

5. Song, D.S.; Yang, J.S.; Oh, J.S.; Han, J.H.; Park, B.K. Differentiation of a Vero cell adapted porcine epidemic diarrhea virus from Korean field strains by restriction fragment length polymorphism analysis of ORF 3. Vaccine 2003, 21, 1833-1842. [CrossRef] 
6. Chang, S.H.; Bae, J.L.; Kang, T.J.; Kim, J.; Chung, G.H.; Lim, C.W.; Laude, H.; Yang, M.S.; Jang, Y.S. Identification of the epitope region capable of inducing neutralizing antibodies against the porcine epidemic diarrhea virus. Mol. Cells 2002, 14, 295-299.

7. Lee, D.K.; Cha, S.Y.; Lee, C. The N-terminal region of the porcine epidemic diarrhea virus spike protein is important for the receptor binding. Korean J. Microbiol. Biotechnol. 2011, 39, 140-145.

8. Sun, D.B.; Feng, L.; Shi, H.Y.; Chen, J.F.; Liu, S.W.; Chen, H.Y.; Wang, Y.F. Spike protein region (aa 636-789) of porcine epidemic diarrhea virus is essential for induction of neutralizing antibodies. Acta. Virol. 2007, 51, 149-156.

9. Nam, E.; Lee, C. Contribution of the porcine aminopeptidase N (CD13) receptor density to porcine epidemic diarrhea virus infection. Vet. Microbiol. 2010, 144, 41-50. [CrossRef]

10. Laude, H.; Gelfi, J.; Lavenant, L.; Charley, B. Single amino acid changes in the viral glycoprotein M affect induction of alpha interferon by the coronavirus transmissible gastroenteritis virus. J. Virol. 1992, 66, 743-749. [CrossRef]

11. Saif, L.J. Coronavirus immunogens. Vet. Microbiol. 1993, 37, 285-297. [CrossRef]

12. Wood, E.N. An apparently new syndrome of porcine epidemic diarrhoea. Vet. Rec. 1977, 100, $243-244$. [CrossRef]

13. Debouck, P.; Pensaert, M. Experimental infection of pigs with a new porcine enteric coronavirus, CV 777. Am. J. Vet. Res. 1980, 41, 219-223. [PubMed]

14. Kawashima, T. Porcine Epidemic Diarrhea (PED) in Japan. In International Conference on Novel Swine Enteric Coronavirus Disease Viruses (nSECDv); Animal and Plant Health Inspection Service: Chicago, IL, USA, 2014; p. 19.

15. Romero-Gonzalez, L.J. Porcine Epidemic Diarrhea in Spain. In International Conference on Novel Swine Enteric Coronavirus Disease Viruses (nSECDv); Animal and Plant Health Inspection Service: Chicago, IL, USA, 2014; p. 29.

16. Park, S.J.; Kim, H.K.; Song, D.S.; Moon, H.J.; Park, B.K. Mocleular characterization and phylogenetic analysis of porcine epidemic diarrhea virus (PEDV) field isolates in Korea. Arch. Virol. 2011, 156, 577-585. [CrossRef]

17. Fan, J.H.; Li, Y.J. Cloning and sequence analysis of the $\mathrm{M}$ gene of porcine epidemic diarrhea virus LJB/03. Virus Genes 2005, 30, 69-73.

18. Cheun-Arom, T.; Temeeyasen, G.; Tripipat, T.; Kaewprommal, P.; Piriyapongsa, J.; Sukrong, S.; Chongcharoen, W.; Tantituvanont, A.; Nilubo, D. Full-length genome analysis of two genetically distinct variants of porcine epidemic diarrhea virus in Thailand. Infect. Genet. Evol. 2016, 44, 114-121. [CrossRef]

19. Chiou, H.Y.; Huang, Y.L.; Deng, M.C.; Chang, C.Y.; Jeng, C.R.; Tsai, P.S.; Yang, C.; Pang, V.F.; Chang, H.W. Phylogenetic Analysis of the spike (S) gene of the new variants of porcine epidemic diarrhoea virus in Taiwan. Transbound. Emerg. Dis. 2017, 64, 157-166. [CrossRef]

20. Song, D.; Moon, H.; Kang, B. Porcine epidemic diarrhea: A review of current epidemiology and available vaccines. Clin. Exp. Vaccine Res. 2015, 4, 166-176. [CrossRef]

21. Huang, Y.W.; Dickerman, A.W.; Piñeyro, P.; Li, L.; Fang, L.; Kiehne, R.; Opriessnig, T.; Meng, X.J. Origin, evolution, and genotyping of emmergent porcine epidemic diarrhea virus strains in the United States. $m$ Bio 2013, 4, e00737. [CrossRef]

22. Suzuki, T.; Murakami, S.; Takahashi, O.; Kodera, A.; Masuda, T.; Itoh, S.; Miyazaki, A.; Ohashi, S.; Tsutsui, T. Molecular characterization of pig epidemic diarrhoea viruses isolated in Japan from 2013 to 2014. Infect. Genet. Evol. 2015, 36, 363-368. [CrossRef]

23. Kim, Y.K.; Lim, S.I.; Lim, J.A.; Cho, I.S.; Park, E.H.; Le, V.P.; Hien, N.B.; Thach, P.N.; Quynh do, H.; Vui, T.Q.; et al. A novel strain of porcine epidemic diarrhea virus in Vietnamese pigs. Arch. Virol. 2015, 160, 1573-1577. [CrossRef]

24. Lee, S.; Lee, C. Outbreak-related porcine epidemic diarrhea virus strains similar to US strains, South Korea. Emerg. Infect. Dis. 2014, 20, 1223-1226. [CrossRef] [PubMed]

25. Jung, K.; Saif, L.J. Porcine epidemic diarrhea virus infection: Etiology, epidemiology, pathogenesis and immunoprophylaxis. Vet. J. 2015, 204, 134-143. [CrossRef] [PubMed]

26. Wang, Y.; Gao, X.; Yao, Y.; Zhang, Y.; Lv, C.; Sun, Z.; Wang, Y.; Jia, X.; Zhuang, J.; Xiao, Y.; et al. The dynamics of Chinese of Chinese variant porcine epidemic diarrhea virus production in Vero cells and intestines of 2-day old piglets. Virus Res. 2015, 208, 82-88. [CrossRef] 
27. Chen, Q.; Li, G.; Stasko, J.; Thomas, J.T.; Stensland, W.R.; Pillatzki, A.E.; Gauger, P.C.; Schwartz, K.J.; Madson, D.; Yoon, K.J.; et al. Isolation and characterization of porcine epidemic diarrhea viruses associated with the 2013 disease outbreak among swine in the United States. J. Clin. Microbiol. 2014, 52, 234-243. [CrossRef]

28. Masuda, T.; Murakami, S.; Takahashi, O.; Miyazaki, A.; Ohashi, S.; Yamasato, H.; Suzuki, T. New porcine epidemic diarrhoea virus variant with a large deletion in the spike gene identified in domestic pigs. Arch. Virol. 2015, 160, 2565-2568. [CrossRef]

29. Su, Y.F.; Hou, Y.; Prarat, M.; Zhang, Y.; Wang, Q.H. New variants of porcine epidemic diarrhea virus with large deletions in the spike protein, identified in the United States, 2016-2017. Arch. Virol. 2018, 163, 2485-2489. [CrossRef]

30. Nguyen, V.D.; Junzo, N.; Masuo, S.; Nguyen, T.L.; Ryoji, Y. Novel Porcine epidemic diarrhea virus (PEDV) variants with large deletions in the spike (S) gene coexist with pedv strains possessing an intact s gene in domestic pigs in Japan: A new disease situation. PLoS ONE 2017, 12, e0170126.

31. Kim, L.; Hayes, J.; Lewis, P.; Parwani, A.V.; Chang, K.O.; Saif, L.J. Molecular characterization and pathogenesis of transmissible gastroenteritis coronavirus (TGEV) and porcine respiratory coronavirus (PRCV) field isolates co-circulating in a swine herd. Arch. Virol. 2000, 145, 1133-1147. [CrossRef]

32. Lu, X.; Rowe, L.A.; Frace, M.; Stevens, J.; Abedi, G.R.; Elnile, O.; Banassir, T.; Al-Masri, M.; Watson, J.T.; Assiri, A.; et al. Spike gene deletion quasispecies in serum of patient with acute MERS-CoV infection. J. Med. Virol. 2017, 89, 542-545. [CrossRef]

33. Park, J.E.; Cruz, D.J.M.; Shin, H.J. Receptor-bound porcine epidemic diarrhea virus spike protein cleaved by trypsin induces membrane fusion. Arch. Virol. 2011, 156, 1749-1756. [CrossRef]

34. Wicht, O.; Li, W.; Willems, L.; Meuleman, T.J.; Wubbolts, R.W.; van Kuppeveld, F.J.M.; Rottier, P.J.M.; Bosch, B.J. Proteolytic activation of the porcine epidemic diarrhea coronavirus spike fusion protein by trypsin in cell culture. J. Virol. 2014, 88, 7952-7961. [CrossRef]

35. Suzuki, T.; Terada, Y.; Enjuanes, L.; Ohashi, S.; Kamitani, W. S1 Subunit of spike protein from a current highly virulent porcine epidemic diarrhea virus is an important determinant of virulence in piglets. Viruses 2018, 10, 467. [CrossRef] [PubMed]

36. Liu, X.; Lin, C.M.; Annamalai, T.; Gao, X.; Lu, Z.; Esseili, M.A.; Jung, K.; El-Tholoth, M.; Saif, L.J.; Wang, Q.H. Determination of the infectious titer and virulence of an original US porcine epidemic diarrhea virus PC22A strain. Vet. Res. 2015, 46, 109. [CrossRef]

37. Thomas, J.T.; Chen, Q.; Gauger, P.C.; Giménez-Lirola, L.G.; Sinha, A.; Harmon, K.M.; Madson, D.M.; Burrough, E.R.; Magstadt, D.R.; Salzbrenner, H.M.; et al. Effect of porcine epidemic diarrhea virus infectious doses on infection outcomes in naïve conventional neonatal and weaned pigs. PLOS ONE 2015, 10, e0139266. [CrossRef]

38. Shan, Z.; Yin, J.; Wang, Z.; Chen, P.; Li, Y.; Tang, L. Identification of the functional domain of the porcine epidemic diarrhoea virus receptor. J. Gen. Virol. 2015, 96, 2656-2660. [CrossRef]

39. Deng, F.; Ye, G.; Liu, Q.; Navid, M.T.; Zhong, X.; Li, Y.; Wan, C.; Xiao, S.; He, Q.; Fu, Z.F. Identification and comparison of receptor binding characteristics of the spike protein of two porcine epidemic diarrhea virus strains. Viruses 2016, 8, 55. [CrossRef]

40. Li, W.; van Kuppeveld, F.J.; He, Q.; Rottier, P.J.; Bosch, B. Cellular entry of the porcine epidemic diarrhea virus. Virus Res. 2016, 226, 117-127. [CrossRef]

41. Li, C.; Li, W.; de Esesarte, E.L.; Guo, H.; van den Elzen, P.; Aarts, E.; van den Born, E.; Rottier, P.J.M.; Bosch, B.J. Cell Attachment domains of the porcine epidemic diarrhea virus spike protein are key targets of neutralizing antibodies. J. Virol. 2017, 91, e00273. [CrossRef]

Publisher's Note: MDPI stays neutral with regard to jurisdictional claims in published maps and institutional affiliations. 